\title{
Exploring Technological Capabilities To Resuscitate The Zimbabwean Manufacturing Sector
}

\author{
Ms. P. Siwadi, North-West University, South Africa
}

Prof. T.G. Pelser, University of KwaZulu-Natal, South Africa

\begin{abstract}
There is widespread agreement that manufacturing concerns require a level of technological capabilities to be able to compete in a globalized economy. This study sought to examine the technological capabilities necessary for the resuscitation of the Zimbabwean manufacturing sector. The sector has been under a lot of pressure mainly from cheaper and sometimes better quality products hailing from international players. With antiquated machinery and having been closed in during and after sanctions, the sector understands the need for up scaling their TCs. The study used data from a non-probability judgemental sample of 77 companies across 6 subsector who had capacity utilization of up to $80 \%$. Return on Assets (ROA) was used to measure performance and was the dependent variable. A total of 14 independent variables were regressed using a bivariate and multivariate regression analysis. Five distinct technological factors proved to positively influence company performance. The significance for industry is that the 5 variables clearly hover around increase in technological capabilities and the support of human resources and information systems to go with it and directs strategists to what they need to recover in the Zimbabwean economy.
\end{abstract}

Keywords: Performance; Technological Capabilities; Human Resources; ISO Certification; Patents; Return On Assets; Manufacturing Sector; Capacity Utilisation

\section{INTRODUCTION}

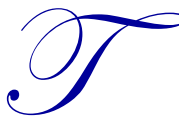

he advent of the knowledge based economy has made the acquisition of knowledge crucial and research has indicated a correlation between superior knowledge and competitive advantage as postulated by Teece et al. (1997) in their study of dynamic managerial capabilities. They advocate that competitive advantage is well determined by the organizational capabilities and core competences and their applications rather than the differences in industry characteristics. The idea then is to combine the specialized knowledge embedded in individuals otherwise known as human capital, with specific organizational activities to enable innovation. Thus technological capabilities (TCs) are now acknowledged as a resource necessary for superior performance. An assessment of science and technology in Africa ranked Zimbabwe 54th in the technology achievement index (TAI), which is very low considering that studies have shown that the TCs area key to economic growth and the benefits and penalties of global technological advances are increasing. The TAI reflects the levels of technological progress and capacity in terms of the creation of technological capabilities. This is the capacity to innovate, the diffusion of recent innovations, the diffusion of existing innovations and the human skills necessary for technology development. Little is known about the development of TCs since Zimbabwe's economic woes began during the year 2000, which saw a number of companies close down. This study sought to empirically examine the relationship between technological capabilities and company performance in an effort to explore the level of preparedness of the manufacturing sector for recovery as far as TCs are concerned. TCs are influenced by a number of variables including ownership, company size, level of research and development, share of skilled workers, investment levels and age of the organisation. 
The study design is aimed at seeking to understand the existence and/or causal technological and performance factors of observed common characteristics or practices in the research study area, specifically due to its inherently multidisciplinary nature. The study area was Harare, as the majority of the manufacturers are located there. The study population was all the manufacturing entities in the six subsectors who are operating above $80 \%$ capacity. This paper contributes to the extant literature in the following ways. First, using a non-probability judgemental sample of 77 companies both private and public from 2009 to 2012 across 6 subsector the researchers provide evidence of the technological capabilities necessary for the Zimbabwean manufacturing sector in the face of globalization. To the best of our knowledge, this paper presents a first attempt at modelling technological capabilities- company performance association within the Sub-Saharan African context, with special reference to Zimbabwe thus significantly increasing the body of knowledge for this developing economy. Secondly, contrary to prior studies we use panel data because better results are obtained by pooling of cross-section and time-series company data. Panel data sets give more data points, more degrees of freedom, reduce co linearity among variables and therefore, produce more efficient estimates than pure cross-sectional or pure time-series data sets. Third, and distinct from most prior studies, we use an econometric model that sufficiently addresses company heterogeneity (i.e. company-specific variables) and time-specific variables which could bias estimates if omitted, as the case in pure cross sectional and time series studies.

The rest of the paper is organised as follows. Section 2 provides an overview of the Zimbabwean manufacturing sector; Section 3 reviews the prior literature on development of technological capabilities and their relation to company performance. Section 4 describes the research methodology. Section 5 reports empirical analyses, while section 6 concludes.

\section{ZIMBABWE MANUFACTURING SECTOR}

\section{Overview Of The Manufacturing Sector}

The manufacturing sector is one of the four wealth-generating sectors and is important to Zimbabwe's economy. At its peak in 1999, it was the major contributor to GDP at 22\% (Zimbabwe Statistics Agency, 2010). Although the sector's contribution to the economy has fallen to the current level of about 14\% of GDP, it is the greatest single contributor to the country's GDP, accounting for more than a third of the country's exports (Zimbabwe Statistics Agency, 2010), and it remains an important sector that is critical for the economic development of the country. Although the sector experienced a downturn from 2000 to 2009 during the years of Zimbabwe's worst economic woes, starting from 2000 it is still recognised by government as a key to economic recovery. The sector is responsible for converting at least $60 \%$ of agricultural and mining output, and in turn at least $40 \%$ of its output is consumed by the aforementioned sectors (Ministry of Industry and Commerce, 2011). At present, the manufacturing sector is characterised by high inefficiency as attested by low-capacity utilisation, which averaged $44 \%$ in 2011 . This was partly attributed to the high cost of foreign inputs, raw materials, plants and machinery, and spare parts. This high dependence on foreign inputs reflects the low technological base of the sector (Confederation of Zimbabwe Industries, 2011).

In the government's industrial policy development framework (2011 to 2015), the government expresses clear objectives for the manufacturing sector: to restore the sector's contribution to Zimbabwe's GDP from the current $1.5 \%$ to $30 \%$, and to increase its contribution to exports from $26 \%$ to $50 \%$ by 2015 (Confederation of Zimbabwe Industries, 2011). An average real GDP growth of 15\% is targeted under this framework. Table 1 shows the manufacturing sector's contribution to GDP from 2008 to 2013. The statistics show that the manufacturing sector was a major contributor to GDP. According to the Confederation of Zimbabwe Industries (2011), the sector has yet to restore its significance as its contribution is dwindling every year to very worrisome levels. 
Table 1. Manufacturing Sector GDP Growth/Decline

\begin{tabular}{cc}
\hline Year & GDP Contribution to the Economy (\%) \\
\hline 2008 & 13.3 \\
2009 & 14 \\
2010 & 14 \\
2011 & 14.4 \\
2012 & 2.3 \\
2013 & 1.5 \\
\hline
\end{tabular}

Source: Zimbabwe Statistics Agency (2013)

\section{Zimbabwe Technological Capabilities Context}

The following is empirical literature on the technological capabilities scenario in the Zimbabwe manufacturing sector. The majority of the companies in the manufacturing sector are privately owned (89\%) with only 9 out of 78 companies listed on the Zimbabwean stock exchange being in the manufacturing sector. The majority of the companies $(67 \%)$ do not develop their own technologies though as expected, larger organizations are better than smaller organizations. Further analysis indicates that there is a positive and significant relationship between technology development and ownership as in tandem with Wignaraja (2007,) that foreign owned companies have newer technology than local companies. Surprisingly it was noted that the majority of the companies that imported technology were locally owned. It would be expected that foreign owned and those with mixed ownership would be supported by their sister companies while locally owned companies would develop their own technology. Companies in the developing world tend to benefit from technology from the developed countries with positive results (Benedetto and Zhang 2003; Bilgin et al 2012; Hu et al 2003). In fact developing countries are known as net recipients of technology (Hu et al. 2003, p.1).Even with this low technology development there is transfer of technology to a fair extent.

As expected with little technology development there cannot be much registration and in the period 2009 to 2012 , only 11 patents were registered. In line with the lack of technological development, at least $55 \%$ of the respondents indicated that they have spent money on research and development. According to Teitel (2000) on a study of Zimbabwean manufacturing companies, 'Very little research and development (R\&D) activity takes place, and the results of such work in terms of patents and publications are quite meager, though not below African regional standards.' From 2000 to 2012 perhaps the expenditure on R\&D has improved a little. Only a small number (10\%) of companies published something of a scientific nature. This is in tandem with the findings of Teitel (2000) who noted that there were meagre contributions to scientific publications. Only half of the companies have some kind of linkage. The manufacturing sector in Zimbabwe is highly heterogeneous producing in excess of 6000 different products (Chiripanhura (2010) and companies might not be able to have linkages and some may be unwilling as linkages will mean sharing with the competition. At least half the companies indicated that they have adequate internet for technical development. With the availability of internet providers and the price of data manipulation and distribution going down every year this is a very plausible result. The role of ICTs in development has been recognized by the Zimbabwean government through the creation of a Ministry of Information, communication Technology, Postal and Courier services and such landmark measures as the e-Readiness Survey (2004), and the National ICT Policy Framework (2005) are evidence of this. So companies seem to be following on to the government's initiatives. In terms of relationships with innovative institutions, at least $28 \%$ of the companies have such relations with innovative institutions. Universities can also be roped into such relations and as suggested by (Szogs 2010, p. 33) institutions of higher learning are critical participants in the creation and dissemination of technological knowledge. The majority of the companies (91\%) have some form of human resource development in place. Zimbabwe has a deliberate mechanism for the training of apprentices where companies are compelled to contribute $10 \%$ of their labour bill for the training of human resource at the aforementioned universities, polytechnic colleges and vocational colleges.

\section{PRIOR LITERATURE ON TCS}

The Technological capabilities-company performance discourse requires interrogation of a wide variety of literature to adequately address the multidimensional nature of TCs taxonomies. Progressing from Wang et al. (2006) who postulated TCs as the ability to develop and design new products and processes and upgrade knowledge 
about the physical world in unique ways, thus transforming this knowledge into designs and instructions for the creation of desired outcomes thus taking the mechanical view. Then Wignaraja (2002) posits to combine with the human side of the argument that TCs involves the skills, knowledge and experience that enterprises need to operate technology efficiently it can be concluded that TCs entail the amassed technological knowledge accumulated over a period of time which a company can employ and deploy when developing new products or services and improving existing ones (Kylaheiko et al., 2011).

The idea then is to combine the specialised knowledge embedded in individuals, otherwise known as human capital, with specific organisational activities to enable innovation. Structured thus, TCs can be acknowledged as a resource necessary for superior performance. They have a long-term impact on the growth and performance of companies, especially in developing countries (Iammarino et al., 2008). The newly industrialised economies of East Asia are a case in point where strong development of TCs has resulted in rapid export growth. Hence it can be agreed that TCs have a positive connection with an innovation-based growth strategy (Kylaheiko et al., 2011; Wignaraja, 2002).

As noted, TCs are not fly-by-night quick fixes but are a result of interactive learning and linkages between a numbers of participants (Szogs, 2010). These participants are universities (which are centres of knowledge), technical training institutions, the government (which is the custodian of national policy), research institutions (which create and diffuse technology), and companies themselves. Szogs (2010) further points out that these strong linkages culminate in skills knowledge and infrastructure conducive to the development of TCs. The development of TCs in the manufacturing sector in Zimbabwe, for instance, would require the upgrading of all participants.

\section{Technological Capabilities Dimensions}

Researches have used a myriad of technological capabilities taxonomies depending on the research focus. Technological capabilities is operationalization in this study by the use of three dimensions namely innovation, infrastructure and human resources derived from prior studies which influenced the selection of the following 11 variables.

\section{Technological Development}

Coming up with innovative ways of doing things is critical for companies in the manufacturing sector as some world renowned technologies may not work very well in the Zimbabwean context for instance plants for large scale operations may not be conducive in an environment which has relatively small markets. It is therefore imperative to develop appropriate technology which can be viewed in a positive light in terms of company performance as it diminishes the need and cost of importing technology which might not work (Wignaraja, 2007).

\section{Importation Of Technology}

The diffusion of technology has become easier with the advent of the internet and when companies do not develop their own technologies, importation becomes the one alternative. Conventional wisdom notes that with the proliferation of technology, companies can benefit from importation of technology and in some cases it might be cheaper and faster to purchase than to create your own. Companies in the developing world tend to benefit from technology from the developed countries with positive results (Benedetto and Zhang, 2003; Bilgin et al., 2012; Hu et al., 2003).

\section{Patent Registration}

The registration of patents is an indication of the development of technology in companies. It is evident that an innovation of international acclaim has been discovered and the company is ready to publicly celebrate it (Lee, Lee \& Penning, 2001). Patent registration is an important milestone in building company technological capabilities and understanding whether companies have registered patents or not is well within conventional wisdom. According to Archiburgi and Coco (2005), registration of patents shows the level at which companies are creating their own innovations. 


\section{ISO Certification}

This is an internationally recognized quality certification looking at various aspects of the organization. It is not mandatory for companies in Zimbabwe to garner for this certification and it is companies with international interests or those that want to use it for marketing that actively seek the certification. ISO certification has a positive effect on some aspects of organizations operation and therefore on performance.

\section{Research And Development}

Research and development is the foundation of innovation and investment in it is an indication of a company's commitment to do things better or in a different way (O'Regan et al., 2006). Innovation can lead to better products or more efficient production processes which have an impact on company performance

\section{Contribution To Scientific Publications}

Publications in scientific journals can be considered as an output variable. It is a platform to share results of R\&D and technology creation. This well justifies it as a variable of importance in the technological capabilities and performance conversations (Archiburgi \& Coco, 2005). An assessment of company technological capabilities is therefore incomplete without examining whether companies contribute to scientific publications or not (Archiburgi and Coco 2005)

\section{Presence Of Technological Linkages}

Companies in the manufacturing sector who need technology capabilities utilize linkages for the diffusion of knowledge and technology. The variable looked at the presence of such linkages as they have a bearing on levels of technology as suggested by Lee, Lee and Penning (2001). Strong linkages provide tremendous opportunities for companies to improve their technological capabilities and thus products.

\section{ICT For Technological Developments}

Technological development has prerequisite infrastructure and information technology has become a critical variable in the creation and diffusion of technology and also in the development of other company capabilities. Internet in Zimbabwe accessibility has improved considerably from the year 2000 to 2012 with the $11.5 \%$ of the population now having internet access according to the World Bank internet Statistics (2012). According to the resource based view, information technology is considered a valuable organizational resource that can enhance organizational capabilities and invariably lead to higher company performance. Early contentions by researchers like Wernerfelt (1984) postulated that technological advancement allows the company higher returns and later works (Tanriverdi 2005; Liang \& Liu 2010) closely supports this view.

\section{Relations With Innovative Institutions}

Relations with innovative institutions has been noted in technological development literature as critical for the quick transfer of knowledge and also for cooperation in research and development (Lee, Lee and Penning, 2001; Lall, 1992; Szogs, 2010; Iammarino et al., 2008). Some countries have deliberately set up such institutions whose mandate is to track technologies and adopt them for local companies.

\section{Technology Transfer}

One way developing countries can catch up with developed countries in productivity and technological strength is through transfer of technology (Hu et al., 2003). This aspect is used to assess technological capabilities because if a company is able to transfer technology, it is a developer of such technology though of course transfer can also occur from an organization that has procured it. Companies benefit from technological transfer as it reduces their R\&D expenditure. Transfer can be in the form of direct diffusion from one company to another especially 
between sister companies, through licencing or through foreign direct investment. Technology transfers generally flow from developed to developing countries (Palacios-Marque's et al., 2013).

\section{Human Resource Development}

Human resource development was postulated to be critical for technological development (PalaciosMarque's et al., 2013). Human resource development for technological capabilities is a prerequisite for building appropriate skills to handle innovations or acquired technology. Knowledge resides in people and enhancing them would be critical to the processes, transactions and operations of the organization. Zimbabwe faced a serious skills flight from 2000 to 2008 and skills development was one way organizations could improve performance. It was critical to note the extent to which companies were involved in developing these skills.

\section{METHODOLOGY}

The study undertook a quantitative research design. A quantitative approach utilizes a post positivism paradigm which employs enquiry that uses predetermined instruments that yield statistical data (Creswel, 2007). The nature of the problem requires pooling of cross-section and time-series company data (panel data analysis). The study involves data sets on multiple entities where each entity is observed at more than two points in time, a situation which ogres well with panel data analysis. Panel data sets give more data points, more degrees of freedom, reduce co linearity among variables and therefore, produce more efficient estimates than pure cross-sectional or pure time-series data sets. Panel data methodology gave the researcher greater flexibility in controlling for the effects of company heterogeneity (i.e. company-specific variables) and time-specific variables which could bias estimates if omitted, as the case in pure cross sectional and time series studies (Ehikioya, 2009).

Using non-probability judgemental sampling, a total of 77 questionnaires were administered to companies in 6 subsectors in the manufacturing sector, forming the sample from the population of all the registered manufacturing entities in operating above $80 \%$ capacity utilization in Harare Zimbabwe. A total of 62 questionnaires were usable giving a response rate of $80 \%$. The respondents were wary of releasing data especially financial data given the collection period's proximity to the elections held in July 2013 and the indigenization policy drive which was underway. The researcher used analytical software, STATA, for data analysis. Descriptive statistics concerning the variables were looked at and the results of the regression model came up with critical technological capabilities factors.

\section{Variables}

Coombs \& Bierly III, 2006; Archiburgi \& Coco, 2005; Lall, 1992 and Wignaraja, 2007 suggested the use of patent registration, technology diffusion, ISO certification R\&D expenditure as dependent variables and Return on Assets as the dependent variable. Following on to these studies this research selected technological capabilities measures as indicated in table 2 below.

Table 2. Technological Capabilities Variables

\begin{tabular}{ll}
\hline \multicolumn{1}{c}{ Variable } & \multicolumn{1}{c}{ Description } \\
\hline Patents registered & Company protection of innovations \\
\hline Expenditure on Research and development & $\begin{array}{l}\text { If the company carries out R\& D how much they have spent in the } \\
\text { years in question }\end{array}$ \\
\hline Scientific publications & Publications stemming from the company \\
\hline Creation of technology & Technical knowhow from the company \\
\hline Human resource development & Development of HR in scientific areas \\
\hline Science qualifications & $\begin{array}{l}\text { Number of people in the organization with degrees in scientific } \\
\text { disciplines }\end{array}$ \\
\hline Technology transfer & $\begin{array}{l}\text { Technological development is normally accompanied by the transfer } \\
\text { of technology }\end{array}$ \\
\hline Existence of a relationship with innovation institutions & $\begin{array}{l}\text { Technology generally increases when companies are assisted by } \\
\text { universities or some innovative body }\end{array}$ \\
\hline
\end{tabular}

Source: Adapted from Lall, 1992; Archiburgi \& Coco, 2005; and Wignanaraja 2007 


\section{Regression Model}

Given the panel nature of our data, and as suggested by prior research and random effects method, the following econometric model was used.

$\mathrm{ROA}=T C_{t}$

Where

$\mathrm{ROA}=$ Return on Asserts measuring operating performance

The model was expanded to reflect the 14 technological capabilities variables as suggested by Coombs and Bierly III (2006).

$\mathrm{ROA}=\alpha+\beta_{1} T C D+\beta_{2} I C+\beta_{3} P A+\beta_{4} I S O+\beta_{5} R D+\beta_{6} S P+\beta_{7} T L+S T R+\beta_{9} E L+\beta_{10} I T N+\beta_{11} T E L E+\beta_{12} R I+$ $\beta_{13} T T+\beta_{14} H R D$

Where

ROA $=$ Return on Asserts measuring operating performance

$\alpha_{\text {and }} \beta=$ the parameters to be estimated

$\mathrm{TCD}=$ Technological development

$\mathrm{IC}=$ Importation of technology

$\mathrm{PA}=$ Patent registration

$\mathrm{ISO}=\mathrm{ISO}$ certification

$\mathrm{RD}=\mathrm{R}$ and $\mathrm{D}$ expenditure

$\mathrm{SP}=$ Scientific publications

$\mathrm{TL}=$ Technology linkages

STR $=$ Strength of the linkages

$\mathrm{EL}=$ Electricity for $\mathrm{TC}$ development

ITN= Internet for TC development

TELE $=$ telecommunications for TC development

$\mathrm{RI}=$ Relations with innovative institutions

$\mathrm{TT}=$ Technology transfer

$\mathrm{HRD}=$ Human resource development

FINDINGS

\section{Correlation Matrix}

The validity of the data is indicated by the acceptable correlations within the range of 0.01-0.775 as suggested by Kumar and Singh (2011). Table 3 below shows the correlation. The degree of correlation between independent variables is either low or moderate, suggesting absence of multicolinearity between these variables. 
Table 3. Correlation Matrix

\begin{tabular}{|c|c|c|c|c|c|c|c|c|c|c|c|c|c|c|c|}
\hline & Profit & Techdev & Import & Patent & Iso & rd & Publication & Linkages & Strength & Tctrcture & Internet & $\begin{array}{c}\text { Tele- } \\
\text { communs }\end{array}$ & Relations & Tranfer & Hrdev \\
\hline Profit & 1.0000 & & & & & & & & & & & & & & \\
\hline Techdev & 0.1011 & 1.0000 & & & & & & & & & & & & & \\
\hline Import & 0.0520 & 0.0789 & 1.0000 & & & & & & & & & & & & \\
\hline Patent & 0.1673 & 0.2391 & 0.3036 & 1.0000 & & & & & & & & & & & \\
\hline Iso & 0.1779 & 0.1298 & 0.1355 & 0.2399 & 1.0000 & & & & & & & & & & \\
\hline $\mathrm{Rd}$ & -0.0005 & -0.0566 & 0.4730 & 0.0782 & 0.3868 & 1.0000 & & & & & & & & & \\
\hline Publication & -0.0716 & 0.0073 & 0.0568 & -0.0817 & 0.0234 & 0.1398 & 1.0000 & & & & & & & & \\
\hline Linkages & 0.0362 & -0.0439 & 0.0547 & 0.1146 & -0.1548 & 0.1368 & 0.0774 & 1.0000 & & & & & & & \\
\hline Strength & 0.0280 & 0.0232 & 0.0980 & 0.0930 & -0.0774 & 0.2029 & 0.0183 & 0.8689 & 1.0000 & & & & & & \\
\hline Tctructure & 0.0793 & 0.3416 & -0.0891 & 0.1532 & 0.2897 & -0.0623 & 0.1813 & -0.0150 & -0.0467 & 1.0000 & & & & & \\
\hline Internet & 0.1201 & 0.3743 & 0.1061 & 0.2537 & 0.4859 & 0.0028 & 0.1002 & 0.0143 & -0.0316 & & 1.0000 & & & & \\
\hline Telecommns & 0.0658 & 0.3674 & 0.1937 & 0.1509 & 0.3800 & 0.0109 & 0.0363 & -0.2067 & -0.1974 & & & 1.0000 & & & \\
\hline Relations & 0.0621 & 0.3355 & 0.1013 & 0.1752 & 0.2161 & 0.1145 & 0.2063 & -0.0523 & 0.0775 & & & 0.2008 & 1.0000 & & \\
\hline Transfer & 0.2436 & 0.3294 & 0.1104 & 0.1704 & 0.1781 & 0.0905 & -0.0189 & -0.1018 & -0.0268 & & & 0.1303 & 0.3831 & 1.0000 & \\
\hline Hrdev & 0.0142 & 0.1108 & 0.0573 & -0.0061 & 0.1109 & 0.2184 & 0.4747 & 0.2078 & 0.1505 & & & 0.1450 & 0.2085 & -0.2655 & 1.0000 \\
\hline
\end{tabular}

\section{Regression Analysis}

Given below in Table 4 are the results of the stepwise regression approach to identifying which factors are positive and significantly related to operating performance. All regressions are estimated using the random effects method.

Table 4. Bivariate An Multivariate Regression Analysis

\begin{tabular}{|c|c|c|c|c|c|c|}
\hline & \multicolumn{3}{|c|}{ Bivariate Analysis } & \multicolumn{3}{|c|}{ Multivariate Analysis } \\
\hline Profit & Coef & $\mathbf{Z}$ & $\mathbf{p}>|\mathbf{z}|$ & Coef & $\mathbf{Z}$ & $\mathbf{p}>|\mathbf{z}|$ \\
\hline Techdev & 0.4159566 & 1.47 & 0.141 & -0.880957 & -0.27 & 0.790 \\
\hline Import & 0.2056129 & 0.75 & 0.451 & 0.2323339 & 0.68 & 0.496 \\
\hline Patent & 0.844786 & 2.46 & 0.014 & 0.3655033 & 0.93 & 0.350 \\
\hline Iso & 0.7517696 & 2.62 & 0.009 & 0.7791325 & 1.95 & 0.051 \\
\hline $\mathrm{Rd}$ & -0.0018963 & -0.01 & 0.994 & -0.5499539 & -1.61 & 0.107 \\
\hline Publication & -0.4882866 & -1.04 & 0.298 & -0.7974106 & -1.49 & 0.137 \\
\hline Linkages & 0.1369859 & 0.53 & 0.599 & 0.3688968 & 0.62 & 0.534 \\
\hline Strength & 0.0379769 & 0.41 & 0.685 & -0.0651452 & -0.32 & 0.745 \\
\hline Tctrcuture & 0.1316444 & 1.15 & 0.249 & -0.0090501 & -0.05 & 0.959 \\
\hline Internet & 0.2029513 & 1.75 & 0.079 & 0.0673489 & 0.25 & 0.804 \\
\hline Telecommuns & 0.1023233 & 0.95 & 0.340 & -0.1233716 & -0.58 & 0.562 \\
\hline Relations & 0.2332938 & 0.90 & 0.367 & -0.308598 & -0.98 & 0.326 \\
\hline Transfer & 0.3868849 & 3.64 & 0.000 & 0.4794325 & 3.62 & 0.000 \\
\hline Hrdev & 0.0629996 & 0.21 & 0.837 & 0.7515039 & 1.83 & 0.067 \\
\hline
\end{tabular}




\section{Variable Findings And Discussion}

This section highlights the situation gaining on the Zimbabwean manufacturing sector and the results of the regression analysis are also discussed.

\section{Technological Development}

Technological development which has its backdrop in innovation has an impact on the company's performance but surprisingly the larger companies are not at the forefront of technology development resulting in only $33 \%$ of the companies involved in some form of development. In the majority of cases, the more effective the innovations, the more successful the business (O'Regan et al., 2006). The regression results indicate that innovation is not positively related to company performance. Similar results were noted by (Hatzikian, 2012; Darroch, 2005 and Choi \& Williams, 2013). The studies were carried out across the developed and emerging economies namely Greece, United States of America and Korea and China respectively so country effects may not influence innovation. The results may be in line with the fact that very few companies (33\%) in the sample developed their own technology. In tandem with this (Shiferaw, 2007) in a study of Ethiopian manufacturing companies noted that relatively few companies embark on innovative activities. On the contrary however (Atalay et al., 2013 and Li et al., 2006) found that technological development was positive and significant to company performance. Since country effects do not seem to matter, perhaps innovation significance and support differs from industry to industry.

\section{Importation Of Technology}

It was therefore important to establish whether companies' imported technology as it can indicate levels of technological capabilities in the company. In Zimbabwean manufacturing scenario, (69\%) of the respondents mainly locally owned companies indicated that they import technology. Regression results indicate no association between importation of technology and company performance. Contrary to this, (Branstetter \& Chen, 2006; Bilgin et al., 2012 and $\mathrm{Hu}$ et al., 2003) noted that importation of technology was positive and significant to company performance. This may be because the studies were conducted in the Far East where importation of technology was instrumental in their huge leap into international trade arena.

\section{Patent Registration}

Accordingly the researcher sought to assess the level of technological capabilities for company performance by measuring the establishing whether companies had registered patents. The results indicated a positive association between patent registration and company performance. This is probably because since patents are an indication of innovation, and innovation boosts the technological capabilities of the company and in many cases performance. In agreement, (Simeth \& Cincera, 2013) found patent registration positive and significant to company performance. Contrary to this (Decarollis \& Deeds, 1999; Choi and Williams, 2013; Coombs \& Bierly, 2006) did not find a positive association between patent registration and company performance. In as much as total number of patents is indicative of technological activity, some studies found patent registration negative and not significant to company performance. The probable reason for these differences is that emerging economies are in the throes of upgrading their technologies and patent registration is a critical indicator of technology development whereas developed countries have reached a higher level of technological capabilities and patent registration is no longer as revered and not all innovations directly affect company performance.

\section{ISO Certification}

Obtaining quality certification from the International Organization for Standardization (ISO) has gained popularity the world over. It sends a positive signal that a company has specific quality targets in the making. Zimbabwean companies are struggling for initial or re-registration as the country is recovering but the ISO certification is far below international standards. The regression analysis found a positive and significant association between ISO certification and company performance. This finding was in agreement with several studies across the globe. In emerging economies, (Lafuente et al., 2009) analysed Spanish companies, (Al Refaie et al., 2012) studied Jordanian companies, (Starke et al., 2012) looked at Brazilian companies and (Corbett et al., 2005) examined United 
States companies and noted a positive and significant association between ISO certification and company performance. The reason for this result could be that ISO certification entails improvement in production processes, cost, waste reduction, better management control and quality enhancement all which affect performance. A study done by Simmons and White (1999) was an isolated example of a contrasting view that ISO certification was positive but not significant to company performance. Since ISO certification was popularized in after 2000 this results might make sense.

\section{Research And Development}

At least $55 \%$ of the respondents indicate that they have spent money on research and development. Companies may intensify their internal R\&D expenditure especially for new products or be financed by other companies to carry out $\mathrm{R} \& \mathrm{D}$. Research and development, however, had no positive significance to company performance. This result is in agreement with Shiferaw (2007) who found R\&D expenditure negative and not significant to company performance. The reason is likely because it is not necessarily the expenditure on research and development that matters but the effectiveness and relevance of the development that will affect company performance. Other researchers have however found different results to the contrary. Some found out that expenditure on research and development is positive but not significant to company performance (Coombs \& Bierly 2006, Branstetter \& Chen 2006 and Jam et al., 2011). Others noted that expenditure on R\&D was positive and significant to company performance (Decarolis \& Deeds, 1999 and Hu et al., 2003). Worthy of note is the fact that earlier studies have quite a different view to later studies. And that all these are researches carried outside Africa as opposed to Shiferaw's study of Ethiopian manufacturing companies in 2007.

\section{Contribution To Scientific Publication}

Very few companies (10\%) have contributed to scientific publications a fact also noted by (Teitel, 2000). The regression analysis found no significant relationship between contribution to scientific publications and company performance. The probable reason is that there are costs associated with publications and the Zimbabwean companies are not yet ready to bear the costs. Added to that, companies might think that they do not have much to contribute as this is generally an area for academics and might not see the benefit of publishing. Added to that as pointed out by (Simeth \& Cincera, 2013), there are costs of producing the papers, costs associated with easier imitation by the competition and costs of the loss of the scientist who in publishing have advertised themselves. Other authors however found a positive and significant association between company publication of scientific material and company performance (Simeth \& Cincera, 2013 and Decarolis \& Deeds, 1999).

\section{Presence Of Technological Linkages}

Linkages provide a forum for technological learning in companies and can add as much as $30 \%$ to a company's value addition efforts. Linkages stem from a variety of relationships ranging from customers to suppliers and industry counterparts. These networks enhance a company's ability to gather information and resources pertinent to the development of the organization (Carmeli and Azeroual, 2009 and Chen and Branstetter, 2006). The researchers inquired after the existence of such linkages. At least (45\%) of the companies in the manufacturing sector had technological linkages which were noted as being quite strong. The regression analysis found technological linkages positive but not significant to company performance. A study of Korean companies in 2001 found technological linkages positive and significant to company performance (Lee et al., 2001) and similarly a study of Mexican manufacturing companies later in 2008 also had the same result (Iammarinno et al., 2008). The probable reason for the differences is that in Zimbabwe the culture of linkages is not popular as organizations strive to shield their technologies from competitors. Added to that the Zimbabwean manufacturing sector is highly heterogeneous at one point producing up to 6000 different products and linkages under such circumstances can be difficult. 


\section{Internet For Technological Developments}

At least (37\%) of the companies indicated that their information technology, electricity and telecommunications were adequate for technological development. The regression analysis found a positive association between information technology and company performance. But there was no positive association between electricity resources and telecommunications with company performance. Similar results were noted by Liang and Liu (2010). On the contrary, (Huang et al., 2009, p.15) noted that information technology was negative and not significant to company performance. The reason cited in these studies at variance with the research study is that information technology acts as a conduit for improvement of technological capabilities and directly relating it to company performance might be difficult (Huang et al., 2009).

\section{Relations With Innovative Institutions}

Relationships with such institutions are important as they can lead to valuable technological breakthroughs and it was in the researcher's interest to determine the existence of the partnerships. It was noted that some (45\%) of the companies had fairly strong relationships with a technological facility. The regression analysis found the relationship positive but not significant to company performance. A similar result was found by (Lee et al., 2001) in a research on Korean companies. Iammarino et al., (2008) also noted the same result on a research on Mexican companies. The probable reason for the lack of significance was that research institutions are generally involved in basic research which might not be specific to the needs of the companies. In Zimbabwe for instance, a lot of research is academic in nature and collaboration with companies is not prominent.

\section{Transfer Of Technology}

Technology transfer is taking place to some extent in the majority of companies indicating that even though the companies are not net creators of their own technology they can still transfer that which they have. The regression analysis found that transfer of technology is positively associated with company performance a result shared by (Hu et al., 2003 and Palacios-Marque's et al., 2013). This is probably because Zimbabwe being a developing country benefits tremendously from transfer of technology especially for multinational companies.

\section{Human Resource Development}

Zimbabwe has a deliberate mechanism for the training of apprentices where companies are compelled to contribute $10 \%$ of their labour bill for the training of human resource. This probably contributes to the high positive response. The majority of companies (91\%) are developing skills which is very high. The regression analysis shows a positive association between human resource development and company performance. In tandem with this results (Thang \& Buyens, 2008) found training positive and significant to company performance. This is probably because no amount of technological capabilities can function on its own, which necessitates the human resource element. Contrary to this result, (Schwager et al., 2000) noted that skills development was positive but not significant to company performance). This is probably a Zimbabwean phenomenon where capacity building is a key issue making it very significant.

\section{CONCLUSION}

The Zimbabwean manufacturing sector has been in existence for over 60 years, which should be enough experience to lay strong foundations for TC development. It can be concluded that the country has taken rather a long time to set the TC development agenda, given the loose frameworks, the dependence on FDI (Foreign Direct Investment) and company ownership structures. There has not been gradual, incremental development as in the cases of Mauritius and the Asian 'Tigers', and in fact there has not been much TC development at all. It is apparent that companies have been complacent, which is unacceptable against the backdrop of globalisation which is affecting small economies such as Zimbabwe's.

Technological capabilities afford a company the opportunity to use technology to create competitive advantage as well postulated in the theory of dynamic managerial capabilities. The development and adoption of 
technological capabilities is a must for Zimbabwean companies as this critical stage of their history. These capabilities differ very much between developed and developing countries, the former being largely the innovators heavily involved in creation of technological solutions and the later adopting them to their needs. It can be concluded that in line with the deficiency in Zimbabwe, the results noted that the significant technological capabilities variables hovered around the development of technology. These being ISO certification, patent registration, presence of adequate internet resources and human resource development.

Research has shown that companies that register patents invest heavily in research and development which results in technological breakthroughs that require patent protection as it is a source of competitive advantage. ISO certification is a step up from development where a company requires a stamp of quality by the international body. Added to that are internet resources which are necessary for diffusion of technology. Since Zimbabwe is on the receiving end of technological developments it is necessary to have the internet resources to search for and find appropriate technological capabilities for competitiveness. Human resource development goes hand in hand with acquiring new technologies. Knowledge resides in people and competent human resource is irreplaceable. This fits very well in the Zimbabwean manufacturing sector where companies are recovering and these variables are necessary for technological development.

There has not been empirical research to come up with a technological index for Zimbabwe but it can be concluded that the antiquated manufacturing equipment has negative effects on the competitiveness of Zimbabwe manufacturers. Thus technological development is right down the alley for the majority of companies in the manufacturing sector to improve performance and to be able to offer goods on the international market.

\section{AUTHOR INFORMATION}

Patience Siwadi, Deputy Director, Graduate School of Business Leadership, Midlands State University, Gweru Zimbabwe. She Lectures in Strategic management and business communication. She is a registered PhD student with North West University Mafikeng Campus in her final year of study. Her study area is Dynamic managerial capabilities looking at integration of social capital, corporate governance and technological capabilities for business performance in the Zimbabwe manufacturing sector. She has research interests in strategy implementation, business networking, social capital and technological capabilities for business performance. She is actively involved in Zimbabwe's economic recovery.

Prof. Theuns Pelser is the Dean and Head of School for the Graduate School of Business and Leadership at the University of KwaZulu-Natal, South Africa. He holds a PhD in Strategic Management. His academic interest is strategic management, within the fields of strategic marketing and small business development, especially within the context of technology and innovation management. He holds a $\mathrm{PhD}$ in Strategic Management from the Potchefstroom University. His research focuses on technology strategies, innovation strategies and technology management processes and their relationship to company performance.

\section{REFERENCES}

Branstetter, L., Chen J.R. (2006). The impact of technology transfer and R\&D on productivity growth in Taiwanese industry: Micro-econometric analysis using plant and firm-level data. Japanese and International Economies, 20:177-192.

Chipika, S. \& Wilson, G. (2006). Enabling technological learning among light engineering SMEs in Zimbabwe through networking. Technovation, 26 (8):969-979.

Confederation of Zimbabwe Industries. (2011). Manufacturing survey report. Harare.

Coombs, J.E., Bierly III, P.E. (2006). Measuring technological capability and performance. R\&D Management, 36(4): 421-438.

Das, D.K. (2010). Another perspective of globalization. Journal of International Trade Law and Policy, 9(1):46-63.

Huang M., Ahn, J. and Lee, D. (2009). IT Capabilities and Firm Performance: The Moderating Role of Institutional Pressures and the Mediating Role of IT. Americas Conference on Information Systems (AMCIS) 2009

Proceedings, Innovation Success AIS Electronic Library (AISeL) http://aisel.aisnet.org/amcis2009/653 
Iammarino, S., Padilla-Pérez, R. \& von Tunzelmann, N. (2008). Technological capabilities and global-local interactions: The electronics industry in two Mexican regions. World Development Review, 36(10):19802003.

Kurfi, A.K. (2009). Leadership Styles: The Managerial Challenges in Emerging Economies. International Bulletin of Business Administration, 14(2):55-79.

Kylaheiko, K., Jantunen, A., Puumalainen, K., Saarenketo, S. \& Tuppura, A. (2011). Innovation and internationalization as growth strategies: The role of TCs and appropriability. International Business Review, 508-520.

Ministry of Industry and Commerce. (2011). State of the manufacturing sector report. Harare.

Ministry of Industry and Commerce. (2010). Zimbabwe industry development framework. Harare.

Palacios-Marque's, D. Spain, V. Peris-Ortiz, M. \& Merigo' J.M. (2013). The effect of knowledge transfer on firm performance: An empirical study in knowledge-intensive Industries. Management Decision, 51(5): 973985.

Sachikonye, L.M. (2002). Whither Zimbabwe? Crisis and democratization. Review of African Political Economy, 9(1):13-20.

Shi, Y. (2009). Technological capabilities and international production strategy of companies: the case of foreign direct investment in China. Journal of World Business, 36(2):184-204.

Szogs, A. (2010). Technology transfer and technological capability building in informal companies in Tanzania. Lund, Sweden: Lund University (Thesis - PhD).

Teece, D.J. (2010). Technological innovation and the theory of the company: The role of enterprise-level knowledge, complementarities, and dynamic capabilities. London: Elsevier.

Teitel, S. (2001). Technological competence and company economic performance in Zimbabwe's manufacturing industry. Economics of Innovation and New Technology, 10(6):513-526.

Tödtling, F., Lehner, P. \& Kaufmann, A. (2008). Do different types of innovation rely on specific kinds of knowledge interactions? SRE - Discussion Papers, 2008/01. Vienna: University of Economics and Business.

Van Kleef, J.A.G. \& Roome, N.J. (2007). Developing capabilities and competence for sustainable business management as innovation: a research agenda. Journal of Cleaner Production, 15(1):38-51.

Wang, Y., Zhang, Q. \& Xue, Y. (2006). How technological capability influences business performance: an integrated framework based on the contingency approach. Journal of Technology Management in China, $1(1): 27-52$.

Wignaraja, G. (2002). Company size, technological capabilities and market-oriented policies in Mauritius. Oxford Development Studies, 30(1):87-104.

Wignaraja, G. (2007). Foreign ownership, technological capabilities, and clothing exports in Sri Lanka. ADB Institute discussion paper no. 82.

Wu, H. (2008). When does internal governance make companies innovative? Journal of Business Research, 61:141153.

Zimbabwe Statistics Agency. (2011). National Accounts 2011. Harare. 
NOTES 